\title{
Motifs of M\&A in the US, European and Asian markets
}

\author{
Jaroslav Sedlacek* \\ Faculty of Economics and administration \\ Masaryk University \\ Brno, Czech Republic \\ sedl@econ.muni.cz \\ *Corresponding author
}

\author{
Petr Valouch \\ Faculty of Economics and administration \\ Masaryk University \\ Brno, Czech Republic \\ valouch@econ.muni.cz
}

\begin{abstract}
The subject of this paper is an analysis of the development of activities at the European as well as the Asian market of mergers and acquisitions (M\&A). Causes of mergers and acquisitions and their development mainly in the period after the financial and economic world crisis are examined. A partial study focused on the merger market in the Czech Republic. The analysis results show that numbers of implemented M\&A activities in the Asian market had a similar extent as those in the USA in 2005-2013. The motivations for the activities in M\&A markets change in dependence on the development tendencies of the world economy, politics, continuing liberalization of investment regimes, and implementation of the internationalization strategy on a large scale. The results of our study confirmed the hypothesis that the main motive was the attainment of microeconomic advantages of the merging entities.
\end{abstract}

Keywords-component: company transformations; development of mergers and acquisitions; motives of M\&A

\section{INTRODUCTION}

Transformations of trading companies are closely related to the transformation of national economies into a global economy. Globalization has been in progress for over a thousand years, if we take into account the first trades between Europe and Asia (China); however, in contrast to the presentday globalization, these were largely time-consuming and highly risky economic relationships. The present economy is characterized by the dynamism of changes as regards both the volumes and the speed of capital transfers into the places where higher profits, better conditions for trading, cheaper workforce, etc. can be gained. When searching for possible higher added value, capital has essentially crossed the borders, enforced an unprecedented liberalization of monetary, financial, trading, goods and other flows, and we can also say, got rid of national sentiments. Globalization processes have accelerated and deepened recently. The international scale of economic activities has become commonplace, also because we can hardly delimit what is international or global, and we expect that our economic activities will bring us face to face with partners from other countries of Europe or even other continents. From the economic point of view, globalization is mainly reflected in the increasing significance of knowledge, increase in the numbers of mergers and acquisitions (M\&A), concentration of foreign direct investments, the increasing significance of multinational companies, and by contrast, the decreasing independence of smaller countries and the increasing dependence of economies on foreign trade.

This study concentrates on the causes of transformations of trading companies in the form of mergers and acquisitions. The historical development of trading companies at each moment is accompanied by their transformations, which are implemented with the purpose of stabilizing their financial position and increasing their financial performance. The final aim of the transformations, M\&A as well, is the attainment of a higher economic benefit for their owners.

Transformations can happen in the form of internal (organic) growth of a business, such as reinvestments of incomes, building of new plants, implementation of advanced technologies, or they can be of an external character when the business combines with another or is divided into more businesses. The reason is mainly the assumption that transformations bring a potential to improve in comparison with the current situation and that the resulting form of the company will be stronger, more efficient and will use its advantages in available markets. By combining companies, a concentration of capital occurs accompanied by the creation of a stronger economic group, the ownership structure changes, new organization systems are created and developed as well as various projects in personnel policy, a global company culture and philosophy is born [1].

Markets usually do not distinguish between acquisitions and mergers, which are then considered synonymic. According to West's Encyclopedia of American Law[2]is a merger or acquisition a combination of two companies where one corporation is completely absorbed by another corporation. The less important company loses its identity and becomes part of the more important corporation, which retains its identity. A merger extinguishes the merged corporation, and the surviving corporation assumes all the rights, privileges, and liabilities of the merged corporation. A merger is not the same as a consolidation, in which two corporations lose their separate identities and unite to form a completely new corporation.

In agreement with the global shifting of capital, crossborder or even global M\&A have started to prevail over the local ones starting from some development stage, and this has 
led to the creation of multinational corporations. The aims of this paper are to analyse the M\&A development in Europe and Asia, identify motives for mergers, and indicate possible preferences in the near future.

\section{DEVELOPMENT OF ACTIVITIES IN M\&AMARKETS}

The first references to mergers and acquisitions were observed at the end of the $19^{\text {th }}$ century, when in the USA there was a need for larger investments in business and an effort to stabilize the position of some enterprises in the market. The study into the historical development of company combinations, has proven that activities in the M\&A market did not happen evenly but they fluctuated in dependence on the level of the economic environment, the development of financial markets and mainly the ideas of bidders and target businesses about the price of a takeover. Some authors in this respect use the term merger and acquisition waves - these waves come at a certain level of development of an economy. E.g. Levy and Sarnat[3] talk about 3 waves, Bruner [4] divides the fourth wave into two: a) and b), Martynova and Rennebook[5] differentiate 5 waves and Lipton [6] identifies 6 waves of mergers and acquisitions that represent a considerable deviation from the gradually growing trend of global mergers and acquisitions.

It seems that the length of M\&A waves is shortening; however, another wave could hardly follows the sixth wave immediately, especially because this period was affected by a financial crisis, which then grew into the global economic crisis (2007-2009). Just like studies of top auditing companies and economic institutes [more closely e.g. 7], our previous research
[8] also proved a strong correlation between the development of the world economy in recent years and the volume and number of activities in M\&A markets. M\&A activities gain in the times of economic prosperity and are diminished in the times of depression or stagnation. According to a study by The Boston Consulting Group of 2012, the cyclic character of M\&A is related to the prices of assets, which induce a higher demand even for M\&A in the stock exchange in the periods of a long-term price growth. Price growth in financial markets is usually related to a period when all economy grows. Investors also respond to government incentives, attractiveness of target countries, and the level of risk. To facilitate investors' decisions to enter new markets, several evaluation systems have been created, e.g. The Cass MARC Maturity Index[9]. Investors' attention has been recently directed to fast developing economies in Europe and Asia. The development trends of M\&A activities in both these territories are illustrated by the curves in Fig. 1. The largest number of trades is implemented in European M\&A markets. As expected, the lowest activities are recorded in Asian markets, where the character of target entities prevails as they are purchased by foreign entities, mainly from other continents; however, the differences between the numbers of purchase and sale transactions are not so considerable and they even do not appear in some years. The development curves of activities in M\&A markets provided in Fig. 1 again respond by a decrease in the number of trades implemented during the economic crisis, mainly in the European market. Markets in the USA and Asia seem thus to be more stable.

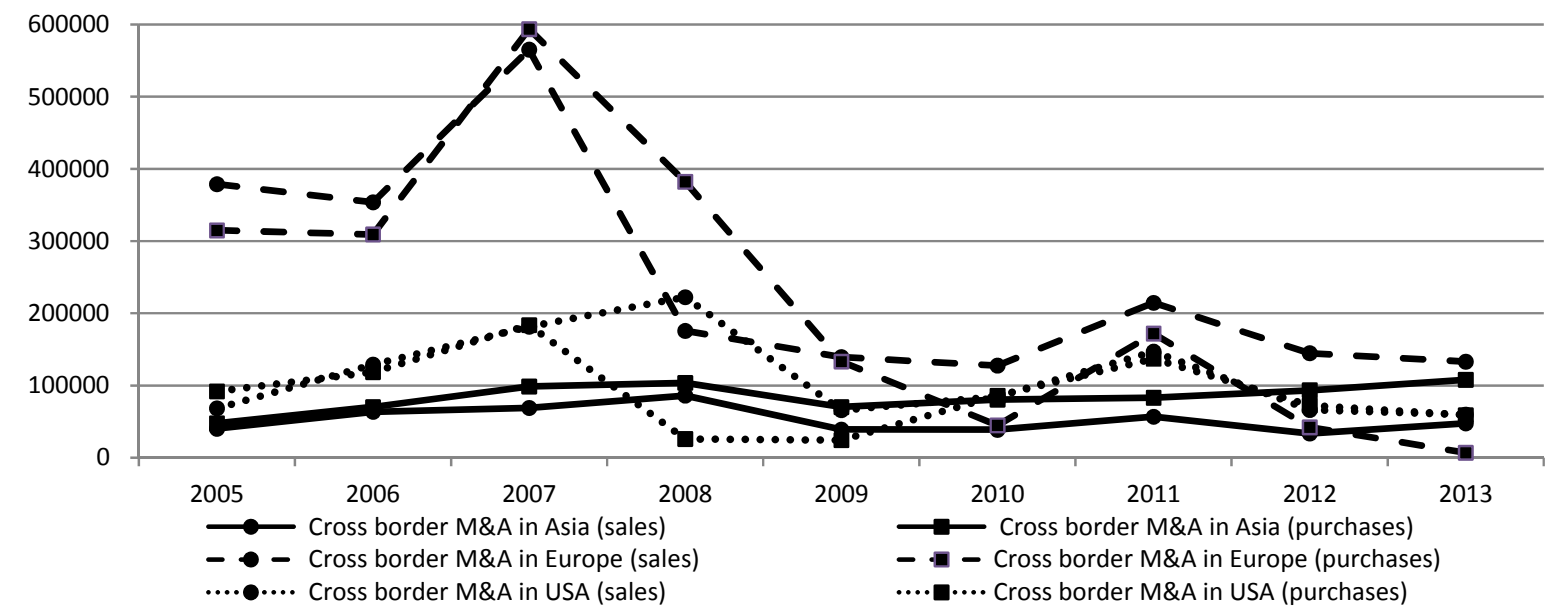

FIGURE I. DEVELOPMENT OF ACTIVITIESON THE M\&A MARKET IN ASIA, EUROPE AND USA (MLD)

\section{The Motives of Mergers AND ACQuisitions}

A merger or an acquisition mean that a trading company gets rid of a part of its capital, which could be otherwise used for its own (organic) development, in order to purchase another company. Therefore, the management may not be always in favour of mergers or acquisitions. Moreover, this process brings an element of instability into an existing organization, as it is necessary to implement new relationships, technological and production processes, organizational culture and management methods. On the other hand, M\&A are attractive because the established aims can be achieved quickly in comparison to a situation when the company starts building e.g. new production facilities in a greenfield. Possible motives for M\&A are mainly the expected microeconomic advantages of the merged entities [10]. Based on the way of reaching the advantages of merging, we distinguish strategic, financial and personal motives [11].

Strategic motives are mainly the efforts to achieve synergic effects. The synergic effect will be created by acquirers if they use a comparative advantage other businesses do not have and the management of the target firm itself is not able to use. The 
synergy from the combination will be usually manifested in the future by achieving higher returns, margins, better use of resources, lower expenses, etc. Trautwein[12] puts synergic effects in the first place among theories motivating M\&A. Brealeyet.al. [13]consider the synergic effect a sensible motive for M\&A and distinguish economies of scale and economies of scope. The economies of scale arise by the distribution of fixed costs into a larger scale of production, which brings a decrease in the costs per a unit of production, while the economies of scope or of activity combination arise due to the concentration and usage of input factors for the production of a broader range of goods. A withdrawal of some operations from the market and their redirecting inside the combined company leads to an elimination of many 'transaction costs' (material, information costs, costs related to negotiations and acceptance of various external trade decisions).

According to Kislingerová[14] strategic motives include the achievement of a higher market share and thus also a higher market power of the company, which makes the obstacles for potential competitors' entrance in the market greater. Another motive for M\&A is often saving of time, as by combination and concentration of capacities products or services can be offered faster or higher quality can be achieved leading to a higher price if the supply meets the demand in the market. An increase in prices and a decrease in the consumers' welfare can even come before the actual implementation of M\&A, as a consequence of a merger being announced. The market synergy can have a form of production diversification, meaning a smaller dependence of the total profit and loss account of a concentrated entity on one product or field. This is an application of the risk portfolio and optimization of the longterm distribution and management of the business risk. A motive can also be a pathological effort to gain a competitor's company and close it.

Often mentioned examples of financial motives are the tax optimization using a tax loss of the purchased company, an increase in earnings per share if the gained company has a lower indicator than the acquiring company, gaining of financial sources with an easier access to capital market (increase in the company's credibility and thus attractiveness of its shares), or the motive of liquidation value in the cases when the liquidation value of a company is higher than its yield value.

Personal motives include the syndrome (hypothesis) of having eyes bigger than the stomach (managers purchase competitors in the effort to be larger without proper calculations), managerial hypothesis saying that the prestige and power of managers depend on the size and growth of the company they manage, managers' protection against hostile takeovers (if there are undistributed funds in the company), management's belief in their ability to use the acquired company's potential better, in their more effective management than the former managers were capable of.

\section{THE ANALYSIS OF MOTIVATION FACTORS IN EUROPEAN AND ASIAN M\&A MARKETS}

As has been mentioned, there are a number of possible motives for M\&A, either strategic or financial; however, the final consequence of these transactions should be an increase in value for owners. The published studies indicate that they are usually strategic investments and their number depends on the development degree of the economy and the situation in the market. E.g. Ogden [15] established the order of motives as shown in the Tab. 1.

Results of research into motives conducted in 1996-1998, which positively affected the success rate of companies, were published by KPMG [16]. The research analysed a sample of 107 companies selected from TOP 700 international M\&A based on the transaction value. The basic criterion of success was the value of shares. The order of themotives isagainshown in theTab. 1.

Similar research was performed by Towers Perrin [17], which examined the influence of human factor on the M\&A success. The survey included 404 respondents from 25 countries; the respondents were executive managers and personnel staff of companies that had implemented one or more transactions in the previous three years. The results are summarized again in Tab. 1 .

TABLE I. COMPARISON OF THE RESUltS OF RESEARCH STUDIES IN THE FIELD OF MOTIVATION M\&A

\begin{tabular}{|l|l|l|l|l|}
\hline & Ogden & KPMG & Towers Perrin & Masaryk University \\
\hline 1. & operational synergy & new geographic market & expansion of products/services & administration simplification \\
\hline 2. & financial synergy and diversification & maximization of share value & geographic expansion \\
\hline 3. & measure against bankruptcy & growth/protection of the market share & response to competition/field & operational synergy \\
\hline 4. & lack of financial sources & acquisition of a new product/ service & maximization of the scope & unification of control structures \\
\hline 5. & $\begin{array}{l}\text { overvaluation of the target company as } \\
\text { regards the added value in the future }\end{array}$ & gaining control over thechannelsof inputs & organizational transformation & stronger market position, new markets \\
\hline 6. & interests of management & access to classified information & acquisition of technologies & simplification of ownership relations \\
\hline 7. & & financial investment & optimization of costs & better access to loans \\
\hline 8. & & & acquisition of talents/abilities & expansion of production portfolio \\
\hline
\end{tabular}

Motivations for M\&A in the Czech Republic were researched using a sample of mergers implemented in recent years[18]. The survey had a form of controlled interviews with employees of the executive management of the companies that had implemented one or more mergers. The aim of the survey was to find the motives for mergers (excluding acquisitions), whether they were strategic and not financial. The actual process was mainly affected by the accounting method of the merger - partners preferred the method of combining shares to the method of purchase. The survey included 59 respondents, who mentioned motivesin the order as shown in Tab.1. 
Motives for M\&A are largely affected by the direction of capital flow. The Czech territory is dominated by local transactions but the proportion of cross-border M\&A has been rising like in other European and Asian countries in dependence on the country's attractiveness for investors. There are developed countries in both the regions, which are considered less risky by investors due to their political stability, economic freedom, mature financial markets, technologies, legal systems and the high socio-cultural level. According to surveys conducted by Allen \&Overy[19], foreign investors' interests regarding M\&A markets have started focusing on China, Japan, Hong Kong, Singapore and India, which are becoming big players, even in the position of the acquirers.

\section{CONCLUSIONS}

The conducted analyses of the historical development of activities in M\&A markets confirmed a recent revival in both examined territories in the period after the financial and economic crisis. From the perspective of location of transactions, local M\&A prevail over the foreign ones. European and Asian markets have recorded investors' interests (of multinational corporations) from developed as well as developing economies. A high increase in activities in the near future is expected for the developing markets in the position of acquirers as well as target companies mainly in China and India

In contrast to Trautwein's theories, a more recent study names expansion of products and services to new geographical markets as the main motives for M\&A. This confirms the hypothesis about the strengthening of cross-border activities at the expense of the local ones - see besides other results the analysis conducted in the Czech merger market [20].

The analysis of a sample of selected mergers implemented in the Czech market in recent years showed that the main motives were simplified administration and tax optimization, which led to cost savings. The combinations of companies that were interconnected by capital or had the same owner prevailed. Although these motives are not declared as ways leading to the increase in value of the acquiring company, we are convinced that in the end, mergers and acquisitions, if successful, will bring a higher wealth for owners.

\section{ACKNOWLEDGMENT}

The paper contains first results of project of Grant Agency Czech Republic no. 403/11/0447 "The Analysis of Taxation and Accounting Procedures during Mergers”.

\section{REFERENCES}

[1] J. Sedlacek and P. Valouch, "Valuation of the Target Company in the n the Process of the Mergers and Acquisitions using Discounted Cash Flow Method," WSEAS Transaction on Business and Economics, vol. 11, pp. 747-756, 2014.

[2] West's Encyclopedia of American Law,[on-line], [cited 2014-06-18]. Available athttp://answers.com/library/LawEncyclopedia-cid-3554923.

[3] H. Levy and M. Sarnat, Capital Investment and Financial Decision. Prague: Grada Publishing, 1999.

[4] R. F. Bruner, Applied mergers and acquisitions. Hoboken: John Wiley \& Sons Inc., 2004.
[5] M. Martynova and L. Rennebook, The Performance of the European Market for Corporate Control: Evidence from the 5th Takeover Wave, Sheffield: ManagementSchool, 2008.

[6] M. Lipton, Merger Waves in the 19th, 20th and 21st Centuries. York University: Osgoode Hall Law School, 2006.

[7] Institute of Mergers, Acquisitions and Alliances (IMAA), Statistics,[online], [cited 2014-07-26]. Available athttp://imaa-institute.org-Statistics on Mergers \& Acquisitions.

[8] J. Sedlacek, P. Valouch and A. Konecny, "Analysis of merger and acquisition development in the Czech Republic in 2001-2010.” Inthe8th International Scientific Conference on Financial Management of Firms and Financial Institutions. Ostrava: VSB TU, p. 384 - 395, 2012.

[9] Cass Business School, The Cass MARC Maturity Index, [on-line], [cited 2014-11-26]. Available athttp://www.cass.city.ac.uk/marc.

[10] J. W. Jeang, G. Bae,“Do acquiring firms knowingly pay too much for target firms? Evidence from earnings management in member-firm mergers in Korean business groups.”Asia-Pacific Journal of Accounting \& Economics,vol. 20, pp. 223-251, 2013.

[11] J. Sedlacek, P. Valouch and A. Konecny, "Synergic motives and economic success of mergers of Czech companies.” Acta Universitatis Agriculturae et Silviculturae Mendelianae Brunensis, vol. 61, pp. 27212727, 2013.

[12] F.Trautwein, “Merger Motives and Merger Prescriptions.”Strategy Management Journal, vol. 11, pp. 283-295,1990.

[13] R. A. Brealey, S. C. Myers and F. Allen. Principles of corporate finance. 8th ed. Boston:McGraw-Hill,2006.

[14] E. Kislingerová,Manažerské finance [Managerial finance]. 3rd ed. Prague: C.H. Beck, 2010.

[15] J. P.Ogden, F. C. Jen and P. F. O’Connor,Advanced Corporate finance, Policies and Strategies. 1st ed. New Jersey, Prentice Hall,2002.

[16] KPMG,Unlocking Shareholders Value - the key to success, [online], [cited 2013-02-2013]. Availableat:http://www.imaainstitute.org/docs/m\&a/kpmg_01_Unlockin g\%20Shareholder\%20Value\%20\%20The\%20Keys\%20to\%20Success.p df.

[17] Towers Perrin, Research study, [on-line], [cited 1 Jun 2013], Available at:http://www.towersperrin.com/tp/getwebcachedoc?webc=USA/2009/2 00912/MA_Pulse_Survey_12-21-09.pdf.

[18] A. Konecny and J. Sedlacek, Manager`s motivation in strategic decision. In Garry Lee. Advances in Education Research. 1st ed. Jeju Island, Korea: Information Engineering Research Institute, USA,. s. 283$289,2013$.

[19] The Allen \& Overy M\&A Index,Insight Report, [on-line]. [cited 201412-22]. Available at:http://www.allenovery.com/news/en-gb/articles/ Pages/The-return-of-MA-2014-the-strongest-year-since-the-crisis.aspx.

[20] J. Sedlacek, P. Valouch and M. Kralova, Economic Efficiency of Mergers in the Czech Republic 2001-2010. Technological and Economic Development of Economy, vol. 19, Supplement 1, pp. S326S341,2013. 